\title{
HCV and HIV Infection among Heroin Abusers in a Methadone Maintenance Treatment Program
}

\author{
Yi-Chieh Lee ${ }^{1}$, Jian-Kang Chao ${ }^{2,3^{*}}$, Ming-Der Shi',4, Mi-Chia Ma5 ${ }^{5}$ I-Chen Chao ${ }^{6}$ \\ ${ }^{1}$ Department of Nursing, Chung Hwa University of Medical Technology, Taiwan \\ ${ }^{2}$ Department of Psychiatry, Pingtung Branch, Kaohsiung Veterans General Hospital, Taiwan \\ ${ }^{3}$ Department of Health Administration, Tzu Chi University of Science and Technology, Taiwan \\ ${ }^{4}$ Department of Pathology and Laboratory Medicine, Kaohsiung Veterans General Hospital Tainan Branch, Taiwan \\ ${ }^{5}$ Department of Statistics, National Cheng Kung University, Taiwan \\ ${ }^{6}$ Department of Medicine, Southeast University, Nanjing, China \\ Email: *jiankangchao2000@yahoo.com.tw
}

How to cite this paper: Lee, Y.-C., Chao, J.-K., Shi, M.-D., Ma, M.-C. and Chao, I-C. (2016) HCV and HIV Infection among Heroin Abusers in a Methadone Maintenance Treatment Program. Health, 8, 12091222.

http://dx.doi.org/10.4236/health.2016.812124

Received: February 18, 2016

Accepted: September 6, 2016

Published: September 9, 2016

Copyright (@) 2016 by authors and Scientific Research Publishing Inc.

This work is licensed under the Creative Commons Attribution International License (CC BY 4.0).

http://creativecommons.org/licenses/by/4.0/

\begin{abstract}
Over the years, it was getting attention to hepatitis $\mathrm{C}$ virus (HCV) and human immunodeficiency virus (HIV) infection among injected drug users (IDUs) in Taiwan. This study investigated the frequency of risky behaviors for HCV carriers and IDUs who were HIV carriers in methadone maintenance treatment program. The subjects, intravenously injected heroin abusers, were collected from a special methadone maintenance treatment clinic. The survey included characteristics of participants, sexual activity and attitude towards condom usage. The total number of subjects was 151. Data were analyzed using the statistical package SPSS 15.0. The analytical methods included descriptive analysis, Fisher's exact test, and the logistic regression model. The study showed that $82 \%$ of intravenously injected heroin abusers were hepatitis $\mathrm{C}$ virus ( $\mathrm{HCV}$ )-positive, and $44.4 \%$ were hepatitis B virus (HBV)-positive; $89.5 \%$ of HIV-positive heroin abusers were type C hepatitis positive. Only $21.2 \%$ of these intravenously injected heroin abusers always used a condom, and 39.7\% never used a condom during sexual activity. Logistic regression analysis showed smoking, sharing syringes needles, HBV status and condom use status were four main risk factors on HIV infection. Sharing or using contaminated syringes needles was the main cause of HIV, HBV, and HCV infection in the drug addiction group. Since our government has the policy of providing a methadone maintenance treatment program, the spread of HIV is under control, but knowledge about HIV and safe sex education still needs improvement.
\end{abstract}

${ }^{*}$ Corresponding author. 


\section{Keywords}

Intravenously Injected Heroin Abusers, Human Immunodeficiency Virus, Hepatitis C, Sexual Behavior

\section{Introduction}

Opioid abuse is a complex problem, and not only impacts the affected person's physical and psychological health, but also threatens public security and the level of productivity in society. HIV infection has spread expansively in Taiwan.

The first HIV case in Taiwan was reported in 1984. As of the end of 2013, the total number of HIV cases had been accumulated to 26,475. The number of HIV infections among the injecting drug users (IDUs) began to surge since 2003 and then consistently decreased since Taiwan CDC harm reduction programs [1]. As the drug addiction problem grows, so does the rate of HIV infection. HIV infection may be transmitted by sharing needles or sharing the containers used for mixing that contain the drug. Some studies have shown that patients addicted to opium have more health problems, and that IDUs will suffer from a decrease in life quality and an increased rate of death [2]-[4].

At the end of 2009, 34\% of Taiwanese IDUs also had HIV [5]. Lee found that $80 \%$ $90 \%$ of IDUs had contracted HCV [6]. Survey data have shown that HCV infection is as high as $76.6 \%$, and that more than $90 \%$ of HIV-infected IDUs in China had HIV-HCV co-infection [7] [8]. Most heroin addicts use the intravenous injection method, and commonly share needles or use the same container for the heroin chemical mix. Hence, infectious diseases, such as HIV, HBV and HCV are spread uncontrollably, and HCV is one of the most common infectious diseases in the world [9] [10]. The primary goal of the methadone maintenance treatment program (MMTP) is stemming the spread of HIV, rather than treating heroin dependence; the use or possession of heroin is still illegal in Taiwan. Offenders can choose either to take methadone for at least one year as an outpatient in a hospital or be incarcerated in a residential detoxification or rehabilitation center administered by the Taiwan Ministry of Justice.

Solomon's study pointed out that high-risk behaviors were common and included needle-sharing, unsafe disposal and inappropriate cleaning of needles, and limited condom use. IDUs in India need to be educated on harm reduction and safe-injection practices, and pharmacies could serve as potential venues for HIV prevention interventions in this group [11]. IDUs appear to have been the major group severely affected by HIV in Taiwan; the HIV infection rate has increased year by year in Taiwan, with intravenous injection being the main source of infection. In 2006, the Taiwan Ministry of Justice and Department of Health joined together to conduct a MMTP trial. Heroin addicts who were willing could participate in the trial, and as a reward, the prosecutor would take less stringent action against them.

With the encouragement of the local government and local prosecutor's office, the 
number of participants in the MMTP increased from 252 in 2006 to 11,366 in 2009, and with the advent of the MMTP, the number of cases of HIV infection decreased from 3389 in 2005 to 1938 in 2007 [12]. However, there were reports by participants stating that the difficulty of withdrawing from methadone was significantly greater than withdrawing from heroin. If the addicts cannot successfully withdraw from heroin in the MMTP and also become dependent on methadone, this may lead to a dual addiction, and a situation in which the participants may continue to commit crimes and become involved in the illegal selling of methadone. Prosecutors are not doctors; it is more difficult for them to judge if the patients have successfully withdrawn from the addition. Therefore, it was more important that the drug abusers in MMTP understood that their sexual behavior, continued heroin use, and sharing of needles, diluents and containers were associated with HIV infection [13]-[15].

Thus, the aims of this study were: 1) to evaluate the IDUs with an HIV risk behavior status; and 2) to investigate the association of sexual behavior, continued heroin use, and sharing of needles, diluents and containers with HIV infection in IDUs in MMTP.

\section{Methods and Materials}

\subsection{Participants and Ethical Approval}

This study was based at the MMTP clinic of a hospital in Tainan City. The participants were selected if they were heroin addicts who agreed to participate in this study and signed a consent form (those who were unconscious, or had a severe hearing problem, cognition problem or difficulty understanding the questioners were excluded). The study was reviewed and approved by the Department of Nursing, Chung Hwa University of Medicine and Technology Institutional Review Board (IRB), and was performed during from June 2008 to December 2010. The participants were asked to go through a series of basic physical examinations at the beginning of the study, including chest $\mathrm{X}$-ray, EKG, blood routine, HIV test, urinalysis, and so on. Of the 206 patients at the MMTP clinic, 151 (73.3\%) were willing to participate in the study and able to complete the required study material, as mentioned before.

\subsection{Assessment Instruments}

We used a simple questionnaire for data collection, and the survey consisted of two types of questions.

\subsection{Demographic}

The participant's basic information was collected during the first visit to the MMTP clinic. The questions included gender, marital status, age, educational level, drug history, sexual history, condom use habits in the past year, history of STD, and whether the participants had ever engaged in prostitution for money or drugs.

\subsection{Risk of Unprotected Sexual Behavior-Related HIV}

This survey was done one month after the MMTP clinical study. The main goal of the 
survey was to understand whether the participants had engaged in sexual behavior and needle-sharing behavior after entering the MMTP clinic. There were 10 questions in all, divided into two parts: 5 questions on drug usage behavior (such as how many times did you use intravenously injected drugs this month? How many times did you share a needle with others? How often do you clean your needle equipment before use?), and 5 questions on sexual behavior (such as how many people did you have sexual intercourse with? How often do you use a condom when you have sexual intercourse with your regular sex partner? How many times did you engage in anal sex? How often did you use a condom when you engaged in sexual intercourse with a temporary partner? How often did you use a condom when you engaged in sexual transactions?) Each question was scored from 0 to 5 , according to the rate of occurrence.

\subsection{Method of Study}

At the beginning of the study, staff members explained the content of the survey, the definitions of terms and the method of answering questions, and there were research assistants standing by to answer any questions at all times. This was done to ensure a consistency of data from all participants. After the survey was finished, the data were run though SPSS software for statistical analysis. First, the data were compared with the basic information for descriptive analysis, and then analysis of unprotected sexual behavior within the first month, relative to HCV and HIV-positive IDUs, was carried out. The main focus of the analysis was the variable, "test of HIV infection", as HIV infection will lead to a more serious outcome in intravenous injection-transmitted diseases. In our study, 132 participants were HIV-negative and 19 were HIV-positive, which was a significant difference in ratio; hence, when running the data through cross analysis with multiple variables, many of the fine grid results became zero. When we changed the method of analysis to the chi square test, the expected result would be larger than 5 for an calculated analysis; therefore, we combined the variables that belonged to the same group together, and then ran them through analysis to find the correlation between HIV-positive results and their variables. However, even with the combination of variables, some fine grid variables were still smaller than 5 , so we combined some of the variables together to form one combined category; for example, condom usage was changed to "used in all sexual conduct" or "did not use in all sexual conduct."

HIV testing was performed on serum using HIV ELISA 1.2.0 (Abbott Murex Biotech Limited, Kent, England), repeated using Genscreen HIV 1/2 Version 2 ELISA (BioRad, Marnes-la-Coquette, France) and confirmed using Western blot (BioRad, Marnes-laCoquette, France).

\subsection{Statistical Analysis}

The Statistical Package for the Social Sciences (SPSS) Version 15.0 was used to perform descriptive analysis. Categorical variables were reported as percentage. Differences in proportions were assessed using Fisher's exact tests. A logistic regression model was used to calculate the odds ratio (Table 1); 95\% confidence intervals, abbreviated as CI. 
Table 1. Find HIV-related variables using Fisher's exact test.

\begin{tabular}{|c|c|c|c|c|c|c|c|}
\hline Variable & $\begin{array}{c}\text { HIV } \\
\text { negative } \\
(\mathrm{n}=132)\end{array}$ & $\begin{array}{c}\text { HIV } \\
\text { positive } \\
(\mathrm{n}=19)\end{array}$ & $P$ value & Variable & $\begin{array}{c}\text { HIV } \\
\text { negative } \\
(\mathrm{n}=132)\end{array}$ & $\begin{array}{c}\text { HIV } \\
\text { positive } \\
(\mathrm{n}=19)\end{array}$ & $P$ value \\
\hline Gender & & & 0.472 & MDMA use & & & 1.0 \\
\hline male & $115(87.1)$ & $18(94.7)$ & & Yes & $1(0.8)$ & $0(0)$ & \\
\hline female & $17(12.9)$ & $1(5.3)$ & & No & $131(99.2)$ & $19(100)$ & \\
\hline Marital status & & & 1.0 & Ketamine use & & & 0.334 \\
\hline Ever married & $47(35.6)$ & $7(36.8)$ & & Yes & $2(1.5)$ & $1(5.3)$ & \\
\hline Never married & $85(64.4)$ & $12(63.2)$ & & No & $130(98.5)$ & $18(94.7)$ & \\
\hline Employment status & & & 0.224 & Needle-sharing* & & & $<0.001^{*}$ \\
\hline Employed & $63(47.7)$ & $6(31.6)$ & & Yes & $14(10.6)$ & $12(63.2)$ & \\
\hline Unemployed/Other & $69(52.3)$ & $13(68.4)$ & & No & $118(89.4)$ & $7(36.8)$ & \\
\hline Educational level & & & 0.608 & Sex partner & & & 0.377 \\
\hline$\leq 9$ years & $87(65.9)$ & $14(73.7)$ & & Yes & $104(78.8)$ & $13(68.4)$ & \\
\hline$>9$ years & $45(34.1)$ & $5(26.3)$ & & No & $28(21.2)$ & $6(31.6)$ & \\
\hline Smoking* & & & $0.009^{*}$ & Prostitution & & & 0.494 \\
\hline Yes & $121(91.7)$ & $13(68.4)$ & & Yes & $4(3.0)$ & $1(5.3)$ & \\
\hline No & $11(8.3)$ & $6(31.6)$ & & No & $128(97.0)$ & $18(94.7)$ & \\
\hline Amphetamine use & & & 0.807 & Condom usage ${ }^{*}$ & & & $0.006^{*}$ \\
\hline Yes & $62(47.0)$ & $8(42.1)$ & & Yes & $23(22.3)$ & $8(61.5)$ & \\
\hline No & $70(53.0)$ & $11(57.9)$ & & No & $80(77.7)$ & $5(38.5)$ & \\
\hline Drinking & & & 0.202 & Venereal disease ${ }^{*}$ & & & $0.006^{*}$ \\
\hline Yes & $51(38.6)$ & $4(21.1)$ & & Yes & $10(7.6)$ & $6(31.6)$ & \\
\hline No & $81(61.4)$ & $15(78.9)$ & & No & $122(92.4)$ & $13(68.4)$ & \\
\hline HBV status* & & & $0.046^{\star}$ & HCV status & & & 0.529 \\
\hline yes & $63(47.7)$ & $4(21.1)$ & & Yes & $107(81.1)$ & $17(89.5)$ & \\
\hline No & $69(52.3)$ & $15(78.9)$ & & No & $25(18.9)$ & $2(10.5)$ & \\
\hline $\begin{array}{c}\text { Age at first } \\
\text { amphetamine use }\end{array}$ & & & 0.472 & $\begin{array}{l}\text { Age at first } \\
\text { heroin use }\end{array}$ & & & 1.0 \\
\hline$\leq 20 \mathrm{y} / \mathrm{o}$ & $25(40.3)$ & $2(25.0)$ & & $\leq 20 \mathrm{y} / \mathrm{o}$ & 19(14.4) & $2(10.5)$ & \\
\hline$>20 \mathrm{y} / \mathrm{o}$ & $37(59.7)$ & $6(75.0)$ & & $>20 \mathrm{y} / \mathrm{o}$ & $113(85.6)$ & $17(89.5)$ & \\
\hline
\end{tabular}

${ }^{*} \mathrm{P}<0.05$.

The criterion for statistical significance was set at $\mathrm{p}<0.05$, two-tailed.

\section{Results}

\subsection{Characteristics of IDU in MMTP}

One hundred fifth-one participants were available for analysis. The mean age was 38.22 \pm 7.78 years (range 21 to 64 years). Most of the participants who came to the MMTP clinic were male (88\%), most had an educational level below junior high school, and among them, 54\% were unemployed and near one quarter were without a sex partner. Most of the participants (82.8\%) had not shared a needle one year prior to the MMTP clinic, but 19 participants were HIV-positive IDUs, and 63.2\% of them had shared a needle with someone else one year prior to the MMTP clinic; of the 132 participants who were not HIV-positive IDUs, $10.6 \%$ had shared needles before.

Almost half of the participants (46.4\%) had used amphetamine in the year prior to the MMTP clinic, and only a few had used ecstasy or/and cocaine. The result showed that most of the participants (54.3\%) had first tried amphetamine at the age of 21 to 30 
years, and that $44.3 \%$ of cocaine or/and ecstasy users had tried the drugs at 21 to 30 years of age. Most of the participants (88.7\%) had a smoking habit and $92 \%$ had a HIV screening test before. Most of the IDUs tested positive (82.1\%) for anti-HCV; $44.4 \%$ of the IDUs were HBV-positive IDUs. With regard to condom use in the year prior to the MMTP clinic, $21.2 \%$ of participants reported they had used a condom when they had sexual intercourse, and $39.7 \%$ reported not using a condom during intercourse (Table 2).

\subsection{The Risky Behaviors of HCV Carriers}

Table 3 shows the risk involved with unprotected sexual activity for those IDUs who were HCV-positive IDUs one month after entering the MMTP clinic. Over half of the HCV positive participants still used intravenously injected heroin after one month in the MMTP clinic (51.6\%); 11 (8.9\%) used other people's needles, and 7 (5.6\%) gave their used needles to others to use. Sixteen participants had sexual intercourse with more than one sex partner, 18 participants did not use a condom during sexual

Table 2. Characteristics of IDU in methadone maintenance treatment program (MMTP).

\begin{tabular}{|c|c|c|c|c|c|}
\hline Characteristic & $\mathrm{N}(151)$ & $\%$ & Characteristic & $\mathrm{N}(151)$ & $\%$ \\
\hline Education level & & & Shared any injection equipment, & & \\
\hline$\leq 9$ years & 101 & 66.9 & last 1 month & & \\
\hline \multirow[t]{2}{*}{ Over 9 years } & 50 & 33.1 & No & 125 & 82.8 \\
\hline & & & Yes & 26 & 17.2 \\
\hline Gender & 18 & 11.9 & Amphetamine use, last 1 year & & \\
\hline female & 133 & 88.1 & No & 81 & 53.6 \\
\hline male & & & Yes & 70 & 46.4 \\
\hline Sex partner & 34 & 22.5 & Venereal disease & & \\
\hline No & 5 & 3.3 & No & 135 & 89.4 \\
\hline No fixed, many & 11 & 7.3 & Yes & 16 & 10.6 \\
\hline Fixed, several & 101 & 66.9 & Smoking & & \\
\hline Fixed and only one & & & No & 17 & 11.3 \\
\hline Condom use status & 32 & 21.2 & Yes & 134 & 88.7 \\
\hline Every time & 13 & 8.6 & Alcohol abuse & & \\
\hline Often & 31 & 20.5 & No & 96 & 63.6 \\
\hline Sometimes & 15 & 9.9 & Yes & 55 & 36.4 \\
\hline Rarely & 60 & 39.7 & Any sexual intercourse, last 1 & & \\
\hline Never & & & month & 1 & 0.7 \\
\hline HBV & 84 & 55.6 & Often & 1 & 0.7 \\
\hline negative & 67 & 44.4 & Sometimes & 3 & 2 \\
\hline positive & & & Rarely & 146 & 96.6 \\
\hline Anti-HCV & 27 & 17.9 & Never & & \\
\hline negative & 124 & 82.1 & Age at first heroin use & 21 & 13.9 \\
\hline positive & & & Below 20 y/o & 82 & 54.3 \\
\hline HIV & 132 & 87.4 & $21-30 \mathrm{y} / \mathrm{o}$ & 37 & 24.5 \\
\hline negative & 19 & 12.6 & $31-40 y / o$ & 11 & 7.3 \\
\hline positive & & & Over 41 y/o & & \\
\hline marital status & 97 & 64.2 & Age at first amphetamine use & 26 & 37.1 \\
\hline Never married & 54 & 35.8 & $(\mathrm{n}=70)$ & 31 & 44.3 \\
\hline \multirow[t]{3}{*}{ Ever married } & & & Below 20 y/o & 13 & 18.6 \\
\hline & & & $21-30 y / o$ & & \\
\hline & & & Over 41 y/o & & \\
\hline
\end{tabular}

IDU: Injected drug users; HBV: hepatitis B virus; HIV: human immunodeficiency virus; HCV: hepatitis C virus. 
intercourse with their regular partner, 9 participants did not use a condom during intercourse with temporary sex partners, and 12 participants never used a condom during sexual intercourse (Table 3).

\subsection{The Risky Behaviors of HIV Carriers}

In terms of the numbers and frequency of risky behaviors of IDUs who were HIV carriers after one month of visiting the MMTP clinic, over half of the participants with HIV were still using intravenously injected drugs after entering the MMTP (52.6\%); of these participants, two had used other peoples' needles (10.6\%) and one gave his/her needle to others to use. Among those participants, three had engaged in sexual

Table 3. Number and frequency of risky behaviors of HCV carriers after one month in MMTP.

\begin{tabular}{|c|c|c|c|c|c|}
\hline Drug use items & $\mathrm{N}$ & $\%$ & Sexual behavior items & $\mathrm{N}$ & $\%$ \\
\hline 1. How many times have you & & & 6. How many people, including & & \\
\hline hit up (i.e. injected any drugs) & & & clients, have you had sex with in the & & \\
\hline in the last month? & 60 & 48.4 & last month? & 67 & 68.5 \\
\hline Hasn't hit up & 30 & 24.2 & None & 41 & 27.4 \\
\hline Once a week or less & 12 & 9.7 & One & 15 & 3.2 \\
\hline More than once a week ( $<$ once a & 22 & 17.7 & Two & 1 & 0.8 \\
\hline day) & & & Over 10 people & & \\
\hline$>$ Once a day & & & 7. How often have you used condoms & & \\
\hline 2. How many times in the last & & & when having sex with your regular & & \\
\hline month have you used a needle & 113 & 91.1 & partner(s) in the last month? & 71 & 57.3 \\
\hline after someone else had already & 8 & 6.5 & No regular partner/no penetrative sex & 16 & 12.9 \\
\hline used it? & 3 & 2.4 & Every time & 10 & 8.1 \\
\hline Never & & & Often & 1 & 0.8 \\
\hline One time & & & Sometimes & 8 & 6.5 \\
\hline Two times & & & Rarely & 18 & 14.5 \\
\hline 3. How many different people & 116 & 93.5 & Never & & \\
\hline have used a needle before you & 5 & 4.0 & 8. How often have you used condoms & & \\
\hline in the last month? & 2 & 1.6 & when you had sex with casual & 90 & 72.6 \\
\hline Never & 1 & 0.8 & partners? & 10 & 8.1 \\
\hline One person & & & No casual partners. no penetrative sex & 6 & 4.8 \\
\hline Two person & & & Every time & 1 & 0.8 \\
\hline 3 - 5 people & & & Often & 8 & 6.5 \\
\hline 4. How many times in the last & 117 & 94.4 & Sometimes & 9 & 7.3 \\
\hline month has someone used a & 4 & 3.2 & Rarely & & \\
\hline needle after you have used it? & 2 & 1.6 & Never & & \\
\hline Never & 1 & 0.8 & 9. How often have you used condoms & 89 & 71.8 \\
\hline One time & & & when you have been paid for sex in & 9 & 7.3 \\
\hline Two times & & & the last month? & 6 & 4.8 \\
\hline $3-5$ times & & & No paid sex/no penetrative sex & 3 & 2.4 \\
\hline 5. How often, in the last month, & 82 & 68.2 & Every time & 5 & 4.0 \\
\hline have you cleaned needles & 34 & 26.5 & Often & 12 & 9.7 \\
\hline before re-using them? & 5 & 3.3 & Sometimes & & \\
\hline Does not re-use & 2 & 1.3 & Rarely & & \\
\hline Every time & 1 & 0.7 & Never & 123 & 99.2 \\
\hline Often & & & 10. How many times did you have & 0 & 0 \\
\hline Sometimes & & & anal sex in the last month? & 1 & 0.8 \\
\hline \multirow[t]{4}{*}{ Never } & & & Never & 0 & 0 \\
\hline & & & 1 time & & \\
\hline & & & 2 times & & \\
\hline & & & 3 - 5 times & & \\
\hline
\end{tabular}


intercourse with more than one sex partner, four never used a condom during intercourse with their regular partner, one never used a condom during intercourse with a temporary sex partner, and one participant had never used a condom during sexual intercourse (Table 4).

\subsection{HIV-Related Variables}

In the analysis of the HIV-positive IDUs, up to $89.5 \%$ (17/19) were HCV-positive, and about $21.1 \%$ (4/19) were HBV-positive; 68.4\% (13/19) of subjects had a sex partner within the year before entering the MMTP, $61.5 \%$ (8/13) used a condom each time they had sex, but up to $38.5 \%$ (5/13) of HIV-positive IDUs did not use a condom during sexual intercourse. Fisher's exact test showed that "smoking", "HBV", "needle-sharing", "condom usage" and "venereal disease" were the five variables significantly associated with HIV (Table 1).

Based on these results, we used needle-sharing, condom usage, venereal disease, HBV and smoking as factors to analyze in the stepwise logistic regression model. Stepwise

Table 4. Number and frequency of risky behaviors of HIV carriers after one month in MMTP.

\begin{tabular}{|c|c|c|c|c|c|}
\hline Drug use items & $\mathrm{N}$ & $\%$ & Sexual behavior items & $\mathrm{N}$ & $\%$ \\
\hline 1. How many times have you hit up & & & 6. How many people, including & & \\
\hline (i.e. injected any drugs) in the last & & & clients, have you had sex with in & & \\
\hline month? & 9 & 47.4 & the last month? & 9 & 47.4 \\
\hline Hasn't hit up & 3 & 15.8 & None & 7 & 36.8 \\
\hline Once a week or less & 4 & 21.1 & One & 3 & 15.8 \\
\hline More than once a week (<once a day) & 3 & 15.8 & Over two people & & \\
\hline$>$ Once a day & & & 7. How often have you used & & \\
\hline 2. How many times in the last month & & & condoms when having sex with & & \\
\hline have you used a needle after someone & & & your regular partner(s) in the & 9 & 47.4 \\
\hline else had already used it? & 17 & 89.5 & last month? & 4 & 21.1 \\
\hline Never & 1 & 5.3 & No regular partner/no penetrative & 2 & 10.5 \\
\hline One time & 1 & 5.3 & $\operatorname{sex}$ & 4 & 21.1 \\
\hline Two times & & & Every time & & \\
\hline 3. How many different people have & & & Often & & \\
\hline used a needle before you in the last & 18 & 94.7 & Never & 16 & 84.2 \\
\hline month? & 1 & 5.3 & 8. How often have you used & 1 & 5.3 \\
\hline Never & & & condoms when you had sex with & 1 & 5.3 \\
\hline One person & & & casual partners? & 1 & 5.3 \\
\hline 4. How many times in the last month & 18 & 94.7 & No casual partners. no penetrative & & \\
\hline has someone used a needle after you & 1 & 5.3 & sex & & \\
\hline have used it? & & & Every time & & \\
\hline Never & & & Often & 15 & 78.9 \\
\hline One time & 14 & 73.7 & Never & 3 & 15.8 \\
\hline $\begin{array}{l}\text { 5. How often, in the last month, have } \\
\text { you cleaned needles before re-using } \\
\text { them? }\end{array}$ & 5 & 26.3 & $\begin{array}{l}\text { 9. How often have you used } \\
\text { condoms when you have been } \\
\text { paid for sex in the last month? }\end{array}$ & 1 & 5.3 \\
\hline Does not re-use & & & No paid sex/no penetrative sex & 19 & 100.0 \\
\hline \multirow[t]{4}{*}{ Every time } & & & Every time & & \\
\hline & & & Never & & \\
\hline & & & 10. How many times did you & & \\
\hline & & & have anal sex in the last month? & & \\
\hline
\end{tabular}

MMTP: Methadone maintenance treatment program. 
logistic regression analysis found significant differences in needle-sharing (odds ratio $=$ $12.375, \mathrm{p}<0.001$ ), condom usage (odds ratio $=5.565, \mathrm{p}=0.005$ ), venereal disease (odds ratio $=5.538, \mathrm{p}=0.004)$ and $\mathrm{HBV}($ odds ratio $=0.292, \mathrm{p}=0.037)($ Table 5$)$.

\section{Discussion}

\subsection{Methadone Maintenance Treatment Program}

Methadone treatment was introduced in Taiwan in 2006 as a harm-reduction program in response to HIV, which is endemic among Taiwanese heroin users. Methadone maintenance therapy primarily provides heroin-dependent patients with long-term methadone and recovery plans, such as hygiene training, routine physical and mental health checkup, urine tests, and group psychological counseling [16]. Methadone treatment can help prevent many blood-transmitted diseases (HIV, syphilis, B hepatitis, C-type hepatitis) caused by sharing needles. MMTP may increases the probability that drug addicts can live a normal life, work and go back to the community, have the opportunity to live a day without looking for drugs, and commit fewer crimes. So methadone treatment minimizes the damage that IDUs may do to people and the community.

\subsection{The Risky Behaviors of HIV Carriers and HCV Carriers}

The IDUs in the Tainan County community MMTP were mainly young men, less educated and more likely to be unemployed. Most patients in MMTP did not share syringes during the previous year (82.8\%); this result was similar to that in Hou's study, which found that $13.9 \%$ of IDU subjects had shared injection equipment [17]. However, this study also showed that $63.2 \%$ (12/19) of these HIV-positive IDUs had shared needles. This was more than that reported by the CDC in 2010, in which the proportion of IDUs infected with HIV-1 increased from 1.7\% (13/772) in 2002, to $72.4 \%$ (2461/ $3399)$ in 2005 , and dropped to $32.15 \%(6448 / 20,057)$ in 2010 [5]. Chen's study also pointed out that the most important risk factor for Taiwanese intravenous drug users is needle sharing, followed by the sharing of heroin diluents [18]. Since they commonly share injection equipment (needles), and HCV and HIV are transmitted mainly through blood and serum, IDUs are highly susceptible to HCV, HIV [19]-[22] and HBV, among other blood-borne infections. Estimates of the prevalence of HIV among Indian IDUs encompass a broad range, from $1 \%$ to $68 \%$ [23], with recent national estimates suggesting a prevalence of $15 \%$ among IDUs older than 25 years [24].

Our study results showed that a reduced proportion-52.6\% (10/19)—of HIV infected

Table 5. Multiple logistic regression analysis of HIV-related variables.

\begin{tabular}{ccccc}
\hline Variable & $\mathrm{B}$ & P-Value & OR & $95 \%$ CI \\
\hline Needles-sharing & 2.516 & $<0.001^{*}$ & 12.375 & $4.22,36.29$ \\
Condom usage & 1.717 & $0.005^{*}$ & 5.565 & $1.66,18.66$ \\
Venereal disease & 1.712 & $0.004^{*}$ & 5.538 & $1.73,17.72$ \\
HBV & -1.231 & $0.037^{*}$ & 0.292 & $0.09,0.93$ \\
\hline
\end{tabular}

${ }^{*} \mathrm{p}<0.05$. 
patients with heroin abuse within one month after entering MMTP still used intravenous drugs, and the proportion of those letting others use their used syringes dropped to $10.6 \%(2 / 19)$. These results show that the reduction of cases of sharing syringes with others again is worthy of consideration. IDUs have a risk of HIV infection. In addition to sharing HIV-contaminated needles and diluents with others, previous studies have pointed out that the IDUs continue to engage in risky sexual behaviors, including multiple sex partners, prostitution and unprotected sexual intercourse [25]-[27]. The results also show that these HIV-positive IDUs have sex with temporary partners, and that one participant (1/19) never used condoms, even in the sex trade. Also, 1/3 of drug addicts that were HIV-positive IDUs were asexual, and those with sexual partners mostly had a steady partner, but there were still 3 subjects that had a number of sexual partners. It is noteworthy that condom usage among drug addicts with HIV was high, but there were still 4 HIV-positive IDUs (4/19; 21.1\%) that used condoms frequently or occasionally and 1 HIV-positive IDU resorted to prostitution for money or heroin, which should be given very careful attention. Studies among HIV-positive IDUs who know their HIV status show high rates of HIV-related risky behaviors, including the sharing of needles and syringes [28] [29], multiple sexual partners [30] and unprotected sexual intercourse [31].

HIV infected patients may use sex or prostitution to obtain heroin, and thereby further spread HIV to others. Therefore, we have the necessary education in the MMTP OPD to promote safe sex and condom use. Overall, up to $82 \%$ of these subjects are $\mathrm{HCV}$-positive IDUs and about $44.4 \%$ are HBV infected patients; these rates are higher than those in Garten's data from southern China and in Solomon's study [32] [33], but similar to the rates in Kheirandish's report and Lee's report [34] [35]. In those with HCV infection, $80 \%$ to $85 \%$ will develop chronic hepatitis, and nearly $20 \%$ to $30 \%$ of subjects will develop liver cirrhosis after 20 years, and possibly even liver cancer [36]. Yen's study also points out that Taiwanese IDUs in the MMTP have a high HIV prevalence, which was associated with syringe sharing and other factors related to social marginalization. Because IDUs commonly share injection equipment needles, and HCV and HIV are transmitted mainly through blood and serum, IDUs are highly susceptible to HCV and HIV [19]-[21]. These patients must know that public health and clinical medical care are extremely important issues, but also more integrated medical services should be provided to heroin-using populations.

\subsection{The Benefits of Methadone Programs for Public Health}

The government's promotion of clean needle exchange programs and methadone substitution treatment to block future sharing of needles by IDUs and lower the incidence of HIV infection can lead to the avoidance of serious social problems and reduce the burden on the national economy. Providing methadone to heroin users not only limits needle sharing, thereby stemming the spread of infectious diseases, but also treats addiction and the drug-related effects of heroin dependence, which affect the drug user's quality of life. Since 1994, Taiwan has been promoting the MMTP, and the numbers of newly infected Taiwanese HIV-1 patients presenting in 2007 and 2010 have been flat or 
down; this is due to the government implementing clean needle exchanges, and the MMTP policy of reducing the HIV, HBV, and HCV epidemic. Lee's study also points out that HIV testing and education was essential for effective HIV control upon implementation of the national pilot harm reduction program (PHRP) [37]. Due to the implementation of the MMTP, drug users, whether through direct (mandatory health education and group psychotherapy) or indirect methods (dissemination of information, etc.), have gained knowledge about HIV and risky sexual behaviors. Our study results also demonstrated that both drug-and sex-related risky behaviors decrease during MMTP, and emphasized the benefits of methadone programs for public health and HIV/HCV prevention, similar to the results of Willner-Reid's data [38].

\subsection{The Limitations of Study}

The limitations of this study include the small sample size and lack of exhaustive recruitment of IDUs deep within methadone clinics in southern Taiwan, so this study cohort may not constitute a representative sample of Taiwanese heroin users. Second, since risky behavior was assessed through a questionnaire, it was not possible to validate whether the patients answered the questions truthfully. We attempted to alleviate this problem by providing our participants with confidentiality.

\section{Conclusion}

In conclusion, the sharing of needles or dilution solvents within the drug addiction group is the main cause of HIV, HBV, and HCV infection. This is one of the most important problems in public health and clinical care. Since our government has an MMTP policy, the spread of HIV has come under control, but knowledge about HIV and safe sex education still need improvement. It is important for prevention programs to improve awareness of infection status through more regular HIV and HCV screening and to better educate IDUs about the utility of infection status disclosures within their drug injecting networks.

\section{Author Contributors}

Conceived and designed the experiments: JKC YCL MDS MCM ICC. Performed the experiments: JKC YCL MDS. Contributed reagents/materials/analysis tools: JKC YCL MDS. Wrote the paper: JKC YCL MDS MCM ICC.

\section{Competing Interests}

The authors have declared that no competing interests exist.

\section{References}

[1] Taiwan Center for Disease Control. HIV/AIDS. http://www.cdc.gov.tw/english/page.aspx?treeid=e79c7a9e1e9b1cdf\&nowtreeid=6bb9113c9 e323e98

[2] Fischer, B., Rehm, J., Brissette, S., Brochu, S., Bruneau, J., el-Guebaly, N., et al. (2005) Illicit 
Opioid Use in Canada: Comparing Social, Health, and Drug Use Characteristics of Untreated Users in Five Cities (OPICAN Study). Journal of Urban Health, 82, 250-266. http://dx.doi.org/10.1093/jurban/jti049

[3] Ross, J., Teesson, M., Darke, S., Lynskey, M., Ali, R., Ritter, A., et al. (2005) The Characteristics of Heroin Users Entering Treatment: Findings from the Australian Treatment Outcome Study (ATOS). Drug and Alcohol Review, 24, 411-418.

http://dx.doi.org/10.1080/09595230500286039

[4] Bargagli, A. M., Hickman, M., Davoli, M., Perucci, C.A., Schifano, P., Buster, M., Brugal, T. and Vicente, J. (2006) Drug-Related Mortality and Its Impact on Adult Mortality in Eight European Countries. European Journal of Public Health, 16, 198-202. http://dx.doi.org/10.1093/eurpub/cki168

[5] Yen, Y.F., Rodwell, T.C., Yen, M.Y., Hsu, Y.H., Chuang, P., Li, L.H., et al. (2012) HIV Infection Risk among Injection Drug Users in a Methadone Maintenance Treatment Program, Taipei, Taiwan 2007-2010. American Journal of Drug and Alcohol Abuse, 38, 544550. http://www.ncbi.nlm.nih.gov/pubmed/22783806 http://dx.doi.org/10.3109/00952990.2012.702171

[6] Lee, K.C.K., Lim, W.W.L. and Lee, S.S. (2008) High Prevalence of HCV in a Cohort of Injectors on Methadone Substitution Treatment. Journal of Virology, 41, 297-300. http://dx.doi.org/10.1016/j.jcv.2007.09.013

[7] Zhang, C., Yang, R., Xia, X., Cheng H., Choi KH., Zheng X., et al. (2002) High Prevalence of HIV-1 and Hepatitis C Virus Coinfection among Injection Drug Users in the Southeastern Region of Yunnan, China. Journal of Acquired Immune Deficiency Syndromes, 9, 191-196. http://dx.doi.org/10.1097/00042560-200202010-00014

[8] Xia, X., Luo, J., Bai, J., Jia, Y., Lu, F., Zeng, G., et al. (2008) Epidemiology of Hepatitis C virus Infection among Injection Drug Users in China: Systematic Review and Meta-Analysis. Public Health, 122, 990-1003. http://dx.doi.org/10.1016/j.puhe.2008.01.014

[9] Burt, R.D., Hagan, H., Garfein, R.S., Sabin, K., Weinbaum, C., Thiede, H., et al. (2007) Trends in Hepatitis b Virus, Hepatitis c Virus, and Human Immunodeficiency Virus Prevalence, Risk Behaviors, and Preventive Measures among Seattle Injection Drug Users Aged 18-30 Years, 1994-2004. Journal of Urban Health, 84, 436-454.

http://dx.doi.org/10.1007/s11524-007-9178-2

[10] Segurado, A.C., Braga, P., Etzel, A., Yoshida, C.F., Rolla, V.C., Mendes, J.M., et al. (2004) Hepatitis C Virus Coinfection in a Cohort of HIV-Infected Individual from Santos, Brazil: Seroprevalence and Associated Factors. AIDS Patient Care STD, 18,135-143. http://dx.doi.org/10.1089/108729104322994829

[11] Solomon, S.S., Desai, M., Srikrishnan, A.K., Thamburaj, E., Vasudevan, C.K., Kumar, M.S., et al. (2010) The Profile of Injection Drug Users in Chennai, India: Identification of Risk Behaviours and Implications for Interventions. Substance Use and Misuse, 45, 354-367. http://dx.doi.org/10.3109/10826080903452447

[12] Yang, C.H., Chio, M.Y., Huang, Y.F., Chen, T.L., Chen, H.P., Fung, C.P., et al. (2008) Compendium Report-Guidelines for Diagnosis and Treatment of HIV/AIDS. Taiwan Epidemiology Bulletin, 24, 837-844.

[13] Cleland, C.M., Des Jarlais, D.C., Theresa, E., Pouget, E.R., Hagan, H., Coffin, L.S., et al. (2007) HIV Risk Behaviors among Female IDUs in Developing and Transitional Countries. The WHO Phase II Drug Injection Collaborative Study Group. BMC Public Health, 7, 271. http://dx.doi.org/10.1186/1471-2458-7-271

[14] Aceijas, C., Stimson, G.V., Hickman, M., Friedman, S.R., Cooper, H.L., Wiessing, L., et al. (2004) Global Overview of Injecting Drug Use and HIV Infection among Injecting Drug 
Users. Journal of Acquired Immune Deficiency Syndromes, 18, 2295-2303. http://dx.doi.org/10.1097/00002030-200411190-00010

[15] Bluthenthal, R.N., Do, D.P., Finch, B., Martinez, A., Edlin, B.R., Kral, A.H., et al. (2007) Community Characteristics Associated with HIV Risk among Injection Drug Users in the San Francisco Bay Area: A Multilevel Analysis. Journal of Urban Health, 84, 653-666. http://dx.doi.org/10.1007/s11524-007-9213-3

[16] Sees, K.L., Delucchi, K.L., Masson, C., et al. (2000) Methadone Maintenance vs. 180-Day Psychosocially Enriched Detoxification for Treatment of Opioid Dependence: A Randomized Controlled Trial. JAMA, 283, 1303-1310. http://dx.doi.org/10.1001/jama.283.10.1303

[17] Hou, J.Y., Sun, T.C., Huang, C.H., Chen, M.R., Kao, H.A., Hsiao, J.Y., et al. (2009) The Clinical Implications of Methadone Maintenance Treatment for Heroin Addicts in Jail-A Preliminary Report. TSMH Medical \& Nursing Journal, 15, 111-124. (Chinese Version)

[18] Chen, Y.M. (2005) Molecular Epidemiology of HIV-1 Infection among Injecting Drug Users in Taiwan. 2005 Taipei International Conference on Drug Control and Addition Treatment, Taipei, 22-24 November 2005, 22-24.

[19] Bruce, R.D. (2010) Methadone as HIV Prevention: High Volume Methadone Sites to Decrease HIV Incidence Rates in Resource Limited Settings. International Journal of Drug Policy, 21, 122-124. http://dx.doi.org/10.1016/j.drugpo.2009.10.004

[20] Corsi, K.F., Lehman, W.K. and Booth, R.E. (2009) The Effect of Methadone Maintenance on Positive Outcomes for Opiate Injection Drug Users. Journal of Substance Abuse Treatment, 37, 120-126. http://dx.doi.org/10.1016/j.jsat.2008.11.004

[21] Gowing, L.R., Farrell, M., Bornemann, R., Babor, T.F., Farrell, M., Formigoni, M.L., et al. (2006) Methadone Treatment of Injecting Opioid Users for Prevention of HIV Infection. Journal of General Internal Medicine, 21, 193-195. http://dx.doi.org/10.1007/s11606-006-0258-x

[22] Sorensen, J.L. and Copeland, A.L. (2000) Drug Abuse Treatment as an HIV Prevention Strategy: A Review. Drug and Alcohol Dependence, 59, 17-31. http://dx.doi.org/10.1016/S0376-8716(99)00104-0

[23] Aceijas, C., Friedman, S.R., Cooper, H.L., Wiessing, L., Stimson, G.V., Hickman, M., et al. (2006) Estimates of Injecting Drug Users at the National and Local Level in Developing and Transitional Countries, and Gender and Age Distribution. Sexually Transmitted Infections, 82, 10-17. http://dx.doi.org/10.1136/sti.2005.019471

[24] NACO (2006) HIV Sentinel Surveillance 2006 India Country Report. http://www.nacoonline.org/Quick Links/HIV Data/

[25] Brogly, S.B., Bruneau, J., Vincelette, J., Lamothe, F., Franco, E.L., Hulchanski, J.D., et al. (2000) Risk Behavior Change and HIV Infection among Injection Drug Users in Montreal. Journal of Acquired Immune Deficiency Syndromes, 14, 2575-2582.

[26] Riehman, K.S., Kral, A.H., Anderson, R., Sullivan, L.E., Moore, B.A., Chawarski, M.C., et al. (2004) Sexual Relationship, Secondary Syringe Exchange, and Gender Difference in HIV Risk among Drug Injectors. Journal of Urban Health, 81, 249-259. http://dx.doi.org/10.1093/jurban/jth111

[27] Spittal, P.M., Craib, K., Wood, E., Laliberte, N., Hogg, R.S., Li, K., et al. (2002) Risk Factors for Elevated HIV Incidence Rates among Female Injection Drug Users in Vancouver. Canadian Medical Association Journal, 166, 894-899.

[28] Purcell, D.W., Metsch, L.R., Latka, M., Santibanez, S., Gomez, C.A., Eldred, L., et al. (2004) Interventions for Seropositive Injectors-Research and Evaluation: An Integrated Behavioral Intervention with HIV-Positive Injection Drug Users to Address Medical Care, Adherence, 
and Risk Reduction. Journal of Acquired Immune Deficiency Syndromes, 37, S110-S118. http://dx.doi.org/10.1097/01.qai.0000140609.44016.c4

[29] Avants, S.K., Warburton, L.A., Hawkins, K.A. and Margolin, A. (2000) Continuation of High-Risk Behavior by HIV-Positive Drug Users. Treatment Implications. Journal of Substance Abuse Treatment, 19, 15-22. http://dx.doi.org/10.1016/S0740-5472(99)00092-6

[30] Miguez-Burbano, M.J., Pineda-Medina, L., Lecusay, R. and Page, J.B. (2002) Continued High Risk Behaviors in HIV Infected Drug Abusers. Journal of Addictive Diseases, 21, 6780. http://dx.doi.org/10.1300/J069v21n04 07

[31] Latkin, C.A., Forman-Hoffman, V.L., D’Souza, G., Knowlton, A.R., Neblett, R.C., DaveyRothwell, M., et al. (2004) Associations between Medical Service Use and HIV Risk among HIV Positive Drug Users in Baltimore, MD. AIDS Care, 16, 901-908.

http://dx.doi.org/10.1080/09540120412331290239

[32] Garten, R.J., Zhang, J., Lai, S., Liu, W., Chen, J., Yu, X.F., et al. (2005) Coinfection with HIV and Hepatitis C Virus among Injection Drug Users in Southern China. Clinical Infectious Diseases, 41, S18-S24. http://dx.doi.org/10.1086/429491

[33] Solomon, S.S., Srikrishnan, A.K., Mehta, S.H., Vasudevan, C.K., Murugavel, K., Thamburaj, E., et al. (2008) High Prevalence of HIV, HIV/Hepatitis C Virus Co-Infection and Risk Behaviors among IDUs in Chennai, India: A Cause for Concern. Journal of Acquired Immune Deficiency Syndromes, 49, 327-332. http://dx.doi.org/10.1097/QAI.0b013e3181831e85

[34] Kheirandish, P., SeyedAlinaghi, S., Jahani, M., Shirzad, H., Ahmadian, M.S., Majidi, A., et al. (2009) Prevalence and Correlates of Hepatitis C Infection among Male Injection Drug Users in Detention, Tehran, Iran. Journal of Urban Health, 86, 902-908. http://dx.doi.org/10.1007/s11524-009-9393-0

[35] Lee, H.Y., Li, J.H., Wu, L.T., Wu, J.S., Yen, C.F. and Tang, H.P. (2012) Survey of Methadone-Drug Interactions among Patients of Methadone Maintenance Treatment Program in Taiwan. Substance Abuse Treatment, Prevention, and Policy, 7, 11.

http://www.substanceabusepolicy.com/content/7/1/11

http://dx.doi.org/10.1186/1747-597X-7-11

[36] Fattovich, G., Stroffolini, T., Zangni, I. and Donato, F. (2004) Hepatocellular Carcinoma in Cirrhosis: Incidence and Risk Factors. Gastroenterology, 127, S35-S50.

http://dx.doi.org/10.1053/j.gastro.2004.09.014

[37] Lee, H.Y., Yang, Y.H., Yu, W.J. and Li, J.H. (2012) Essentiality of HIV Testing and Education for Effective HIV Control in the National Pilot Harm Reduction Program: The Taiwan Experience. Kaohsiung Journal of Medical Sciences, 28, 79-85. http://dx.doi.org/10.1016/j.kjms.2011.10.006

[38] Willner-Reed, J., Belendiuk, K.A., Epstein, D.H., Schmittne, J. and Preston, K.L. (2008) Hepatitis C and HIV Risk Behaviors in Poly Drug Users on Methadone Maintenance. Journal of Substance Abuse Treatment, 35, 78-86. http://dx.doi.org/10.1016/j.jsat.2007.08.011 
Submit or recommend next manuscript to SCIRP and we will provide best service for you:

Accepting pre-submission inquiries through Email, Facebook, LinkedIn, Twitter, etc. A wide selection of journals (inclusive of 9 subjects, more than 200 journals)

Providing 24-hour high-quality service

User-friendly online submission system

Fair and swift peer-review system

Efficient typesetting and proofreading procedure

Display of the result of downloads and visits, as well as the number of cited articles

Maximum dissemination of your research work

Submit your manuscript at: http://papersubmission.scirp.org/ 